\title{
İlkokul Birinci Sınıf Öğrencilerinin "Sıfır Atık” Kavramı ile İlgili Çizimlerinin İncelenmesi
}

\section{Investigation of the Drawings of Primary School First Grade Students' About the Concept of "Zero Waste"}

Derya Sönmez a,*

a Bilim Uzmanı/Öğretmen, Milli Eğitim Bakanlığı, 46100, Kahramanmaraş/Türkiye. ORCID: 0000-0003-12655-9059

\section{MAKALE BILGIISI}

\section{Makale Geçmişi:}

Başvuru tarihi: 26 Ekim 2019

Düzeltme tarihi: 21 Ocak 2020

Kabul tarihi: 11 Şubat 2020

\section{Anahtar Kelimeler:}

Birinci Sınıf Öğrencileri,

Çevre,

İlkokul,

Kavram,

Sifir Atık.

\section{ÖZ}

Bu çalışmada ilkokul birinci sınıf öğrencilerinin sıfır atık kavramı ile ilgili çizimlerinin incelenmesi amaçlanmıştır. Araştırmada nitel araştırma yöntemlerinden olgu bilim (fenomenoloji) deseni kullanılmıştır. Araştırmanın çalışma grubunu 2019-2020 eğitim-öğretim yılı güz dönemi Kahramanmaraş ili Merkez ilçesinde bulunan bir ilkokulun birinci sınıfında öğrenim gören 18 öğrenci oluşturmuştur. İlkokul birinci sınıf öğrencilerinin sıfır atık kavramına yönelik algılarını belirlemek için çizim yapmaları ve çizimlerini anlatmaları istenmiştir. Verilerin analizinde içerik analizi kullanılmıștır. Öğrencilerin çizdikleri resimler görüşmelerdeki açıklamaları da dikkate alınarak analiz edilmiştir. Öğrencilerin çizimleri ve görüşleri kodlanarak sunulmuştur. İlkokul birinci sınıf öğrencilerinin sıfır atık kavramı ile ilgili çizimleri incelendiğinde resimlerde en fazla çöp kavramına yer verdikleri tespit edilmiştir. Kız öğrencilerin atık bilinci teması, erkek öğrencilerin çevre koruma teması ile ilgili kavramlara daha çok yer verdikleri tespit edilmiştir.

\section{ARTICLE INFO}

\section{Article history:}

Received 26 October 2019

Received in revised form 21 January 2020

Accepted 11 February 2020

\section{Keywords:}

First Grade Students,

Environment,

Primary School,

Concept,

Zero Waste.

\section{A B S T R AC T}

In this study, it is aimed to examine the drawings of first grade primary school students about zero waste concept. Phenomenology design, one of the qualitative research methods, was used in the study. The study group of the study consisted of 18 students in the first year of a primary school in the central district of Kahramanmaras province in the fall semester of 2019-2020 academic year. First grade students were asked to draw and explain their perceptions about the concept of zero waste. Content analysis was used in the analysis of the data. The pictures of the students were analyzed by considering the explanations in the interviews. The drawings and views of the students are presented by coding. When the drawings of first grade primary school students about the concept of zero waste were examined, it was found that they included the most garbage concept in the pictures. It was found that female students give more importance to the concepts of waste awareness and male students to environmental protection theme.

\section{Giriș}

İnsanların bilinçsizce yaptıkları bazı olumsuz davranışların sonucunda, yaşadıkları çevrede değişiklikler meydana gelmektedir. Bu değişiklikler, yalnızca o bölgeyi değil, dünya üzerindeki diğer bölgeleri de etkilemektedir. Gerek bilgi eksikliğinden gerekse yanlış davranışlardan dolayı çevre üzerinde, insanlardan kaynaklanan bu değişiklikler, sorunlara ve ileri boyutlarda, doğada tahribata yol açmaktadır (Çabuk, 2019). Çevremizi etkileyen en önemli etkenlerden birisi de atıklardır. Nüfusun hızla çoğalmasından kaynaklanan atıkların önlenemez artışı sonucu, önceleri atıkların gömülmesi yoluna gidilmiş, sonrasında gömme kapasitelerinin azalması ve gömülen atıkların toprağa verdiği zararlar nedeniyle, geri kazanım sistemleri kurulmaya başlanmıştır. Atıkların üretim/tüketim miktarını azaltmak ve ayrıca atıkların geri dönüşümüne destek olmak tüm insanların başlıca görevlerindendir.

\footnotetext{
* Sorumlu yazar/Corresponding author
}

e-posta: deryasnmzim@hotmail.com 
Bunun anlaşılmasıyla birlikte, birçok ülkede önemli girişimler başlatılarak atık halindeki tüm değerlendirilebilir malzemelerin, malzeme ve/veya enerji şeklinde geri kazanımı genel hedefler arasında yerini almıştır (Kaçtıoğlu ve Şengül, 2010).

Tüm bu gelişmeler çerçevesinde özellikle son yıllarda geri dönüşüme verilen önem oldukça artmıştır. Geri dönüşüme artık sadece bir atık toplama işi olarak bakılmamakta, toplumlar, bu işe çevre bilincinin kazandırılması ve doğal kaynakların korunması amaçlı bir girişim olarak da yaklaşmaktadır (Gürer ve Sakız, 2018). Çevre kirliliğinin zararlarını keşfeden birçok insan bu konularla ilgili ne yapılabilir diye düşünmüş ve çeşitli yaklaşımlar oluşmuştur. Bunlardan en önemlisi dünyada epeyce popüler olan ve gittikçe yaygınlaşan "Zero Waste" yani "Sıfır Atık" uygulamalarıdır (Aydın, 2013).

Sifır atık terimi ilk olarak, 1970'lerin ortalarında Phd. Kimyager Paul Palmer tarafindan Zero Waste Systems Institute firmasının adında kullanılmıştır. Sıfır atık; israfın önlenmesini, atık oluşum sebeplerinin gözden geçirilerek atık oluşumunun önlenmesi ve/veya azaltılmasını, daha sürdürülebilir ürünler tercih edilmesini, kaynakların verimli kullanımının sağlanmasını, atığın oluşması durumunda kaynağında ayrı toplanarak geri kazanımının sağlanmasını kapsayan hedef olarak tanımlanmaktadır (Sifir Atık Yönetmeliği, 2019). Sıfır Atık Projesi; israfın önlenmesi, kaynakların daha verimli kullanılması, oluşan atık miktarının azaltılması, etkin toplama sisteminin kurulması, atıkların geri kazanılması konularını kapsayan bir atık oluşumunu engelleme ve doğru yönetme hedefidir. Bu proje ile hem ekonomik kazanç sağlanacak olup hem de çevremizi koruyarak gelecek nesillere daha yaşanabilir şehirler bırakılacağı öngörülmektedir (Demiral ve Evin, 2018).

Türkiye'de ilk defa 2017 yılında "Sıfır Atık Projesi" olarak duyurulan ve uygulamaya konulan, Türkiye Cumhuriyeti'nin 12.Cumhurbaşkanı Recep Tayyip Erdoğan'ın eşi Sayın Emine Erdoğan himayesinde Çevre ve Şehircilik Bakanlığı takibiyle başlayan projeye öncelikle Cumhurbaşkanlığ 1 Külliyesi ile Çevre ve Şehircilik Bakanlığında başlanmıştır. Türkiye'de israfı önleme, kaynakları daha verimli kullanma, atık miktarını azaltma ve atıkları geri kazanma, yarınlara temiz bir dünya bırakma amacıyla başlatılan "Sıfır Atık" projesi hızla büyümektedir. $\mathrm{Bu}$ proje kapsamında, 01 Kasım 2018'de "Sifır Atık Zirvesi” gerçekleştirilmiştir. Zirvede, bir yıldır sürdürülen projenin; sanayiciler, iş adamları, çeşitli kurumlar, sivil toplum kuruluşları ve üniversiteler tarafından desteklendiği belirtilerek tonlarca ambalaj atığının, elektrikli ve elektronik eşyanın, bitkisel ve madeni atık yağ ile ömrünü tamamlamış lastiğin, kaynağında toplanarak geri kazanıldığına dikkat çekilmiştir (Türkiye Cumhuriyeti Çevre ve Şehircilik Bakanlığı, 2018). Ülke politikası olarak benimsenen "Sıfır Atık" yaklaşımının milli eğitim politikası ve ders öğretim programları ile uyumu ve bunlara yansımaları önem kazanmıştır. Bu bağlamda temel eğitim kademesindeki ilkokullarda ders öğretim programlarının içerik ve kazanımlarının sıfır atık yaklaşımı açısından örtük mesajlar barındırmasının gerekliliği ortaya çıkmıştır. MEB (2018), İlkokul 1, 2 ve 3. Sinıflar Hayat Bilgisi Dersi Öğretim Programının vizyonunda ilkokul çağındaki öğrencilere birey, toplum ve doğa ekseninde temel bilgi, beceri ve değerler kazandırmayı hedefleyen Hayat Bilgisi
Dersi Öğretim Programı çerçevesinde öğrencilerin; "Kendini ve yaşadığı çevreyi tanır. Kaynakları verimli kullanma becerisi geliştirir. Doğaya ve çevreye karşı duyarlı olur." kazanımlarını gerçekleştirmesi beklenmektedir.

İlkokul Hayat Bilgisi Dersi Öğretim Programı 1. Sınıf "Doğada Hayat" temasında "Doğayı ve çevresini temiz tutma konusunda duyarlı olur. Geri dönüşümü yapılabilecek maddeleri ayırt eder." kazanımlarına yer verilmiştir. Geri dönüşüm konusunda plastik, kâğıt, pil, bitkisel yağ ve cam gibi maddeler üzerinde durulması önerilmiştir (MEB, 2018). Bu doğrultuda öğrencilere yaşadığı çevrenin bir parçası olduğu, çevresine zarar vermemesi, çevre sorunların nedenleri ve sonuçları doğrultusunda bilinçlenmesi, atık ve geri dönüşüm konusunda bilgi ve beceri sahibi, topluma ve çevreye karşı duyarlı olması amaçlanmaktadır. Benzer olarak bu amaca yönelik Çakır-Koçak, Tuna-Oran, ÇeberTurfan (2016) tarafından yapılan çalışmada ebelik bölümü öğrencilerinin Topluma Hizmet Uygulamaları dersi kapsamında ilköğretim 4. ve 5. sınıf öğrencilerine verilen atıkların ayrıştırılması eğitiminin bilgi transferi yoluyla aile bilgi düzeyine etkisinin belirlendiği araştırmadır. $\mathrm{Bu}$ çalışmadan farklı olarak sıfır atık farkındalığının okullarımızdaki ders öğretim programlarında örtük olarak yer almasının etkisini öğrencilerin çizimleri yoluyla ortaya çıkarmaktır. Literatüre bakıldığında kavram karikatürünün çoğunlukla kavram yanılgılarının tespit edilmesi ve giderilmesinde kullanıldığı görülmektedir (Demir, 2008; Yıldız, 2008; Say, 2011; Yavuz ve Büyükekşi, 2011; Erdoğan ve Özsevgeç, 2012; Gültekin, 2013; Tokiz, 2013; Atılğanlar, 2014; Meriç, 2014; Arıkurt, 2014).

Sıfır atık ve geri dönüşüm ile ilgili literatürde öğrencilerle ilgili yapılan çalışmaların az olduğu saptanmıştır. UralKeleş ve Keleş (2018) çalışmalarında ilkokul 3. ve 4. sınıf öğrencilerinin geri dönüşüm kavramı ile ilgili algıları; Bulut ve Çavuldur (2017) çalışmalarında ortaokul 6. sınıf öğrencilerinin geri dönüşüm konusunda davranış gelişimleri; Gönüllü ve Çelik (2015) çalışmalarında ilkokul 3 . ve 4. sınıf öğrencilerinin ambalaj atıklarının geri dönüşümü konusunda bilgi düzeyleri; Mutlu (2013) çalışmasında 8. sınıf öğrencilerinin geri dönüşüm algıları; Çimen ve Yılmaz (2012) çalışmalarında ortaokul öğrencilerinin geri dönüşüm ile ilgili davranışlarını; Mrema (2008) çalışmasında 8. ve 11. sınıf öğrencilerinin geri dönüşüm bilgi düzeyleri incelenmiştir. Önal, Kaya ve Çalışkan (2019) çalışmalarında çevre eğitiminde sıfır atık politikası ve 2 . sınıf hayat bilgisi dersi mevcut ders kitaplarındaki görünümünü incelenmişlerdir.

Buradan hareketle ilkokul birinci sınıf öğrencilerinin sıfır atık algısını tespit etmek, yapılan öğretimi gözden geçirmek ve yapılan öğretime yön vermek açısından önem arz etmektedir. İlkokul birinci sınıf öğrencilerinin geri dönüşüm ve sıfır atık algıları geçmiş ve gelecek çevre sorunlarının önlenmesinde etkisinin kuşkusuz önemli olduğu da ortadadır. Bu bağlamda bu çalışmada ilkokul birinci sınıf öğrencilerinin sıfır atık kavramına yönelik algılarının incelenmesi amaçlanmıştır. Bu amaçla aşağıdaki sorulara cevap aranmıştır:

1. İlkokul birinci sınıf öğrencilerinin "sıfır atık" ile ilgili zihinsel imgeleri hangi kavramsal kategoriler altında toplanmaktadır? 
2. İlkokul birinci sınıf öğrencilerinin "sıfır atık" ile ilgili çizimlerindeki temaların cinsiyet değişkenine göre dağılımı nasıldır?

\section{Yöntem ve Uygulama}

$\mathrm{Bu}$ bölümde araştırmanın deseni, çalışma grubu, veri toplama araçları, verilerin toplanması, verilerin analizi, inanırlık (geçerlilik) ve tutarlılık ile ilgili bilgiler sunularak açıklanmıştır.

\subsection{Araştırma Deseni}

$\mathrm{Bu}$ araştırmanın amacı ilkokul birinci sınıf öğrencilerinin sıfır atık kavramı ile ilgili algılarını çizdikleri resimlerle belirlemektir. Bu amaç için nitel araştırma yöntemlerinden olgu bilim (fenomenoloji) deseni kullanılmıştır. Olgu bilim (fenomenoloji) deseni, günlük hayatta farkında olduğumuz fakat derinlemesine ve ayrıntılı bir anlayışa sahip olmadığımız olgulara odaklanır ve bireye tamamıla yabancı olmayan bu olguların detaylı bir şekilde araștırılmasında kullanıılır (Creswell, 2017; Creswell, 2009). Bu araştırmada öğrencilerin sıfır atık algılarının ortaya çıkarılmasında çizimlerden yararlanılması; öğrencilerin çevre ile ilgili duygu ve düşüncelerine doğru bir yol oluşturması ve öğrencilerin çevresi ile olan deneyimlerinin farkına vararak bir sunumuna olanak vermesi açısından araştırmacıya yöntemi oluşturmaları için bir dayanak sağlamıştır.

\section{2. Çalıșma Grubu}

Araştırmanın çalışma grubunu 2019-2020 eğitim-öğretim yılı güz döneminde Kahramanmaraş ili Onikişubat Merkez ilçesinde bulunan bir ilkokulun birinci sınıfında öğrenim gören 10 erkek, 8 k1z olmak üzere 18 öğrenci oluşturmaktadır.

Araştırmada seçkisiz olmayan örnekleme yöntemlerinden biri olan uygun örnekleme yöntemi kullanılmıştır. Bu örnekleme yönteminde araştırmacı yakın ve erişilmesi kolay olan bir grubu seçmektedir. Bu da araştırmaya hız ve pratiklik kazandırır. Ayrıca maliyetin düşük olması da uygun örnekleme yönteminin tercih edilme nedenleri arasındadır (Howitt ve Cramer, 2014).

\subsection{Veri Toplama Arac1}

İlkokul birinci sınıf öğrencilerinin sıfır atık kavramına yönelik algılarını belirlemek için çizim yapmaları ve çizimlerini anlatmaları istenmiştir. Birçok çalışmada çocukların belirlenen konulara yönelik algılarını, imgelerini analiz etmede yaptıkları çizimler güçlü bir araç olarak görülmektedir (Rodari, 2007). Çocuklar tarafindan yapılan çizimler aracılığıyla çocukların iç dünyasına yönelik bilgiyi görsel bir yapı içerisinde anlamlandırmanın, duygularını anlamanın, gerçek düşüncelerini, arzu ve isteklerini belirlemenin mümkün olabileceği belirtilmektedir (Özsoy ve Ahi, 2014). Ancak araştırmacılar, öğrencilerin imgelerinin belirlenmesinde tek başına çizimlerin yetersiz olduğu ve çizimlerin yanında öğrencilerin mutlaka çizimlerini anlatmalarını sağlayacak görüşmelerin yapılması gerektiği vurgulamaktadırlar (Ersoy ve Türkkan, 2010; Ersoy ve Türkkan, 2009). Bu çalışmada da öğrencilerin yapmış oldukları çizimleri anlatmaları için görüşme yapılmıştır.

\subsection{Verilerin Toplanmas1}

İlkokul birinci sınıf öğrencilerin sıfır atık kavramına yönelik yapacakları çizimler için 1 ders saati süre verilmiş ve çizim yapmaları sağlanmıştır. İlkokul birinci sınıf öğrencilerine bu amaç için resim kâğıtları dağıtılmış ve resimlerini boya kullanarak çizmeleri istenmiştir. İlkokul birinci sınıf öğrencilerine çizimleri bitirdikten sonra her bir öğrenci ile yapılan görüşmeler ile çizdikleri resimleri açıklamaları için her bir öğrenci için genel olarak 2-3 dakika süre ayrılmıştır.

\subsection{Verilerin Analizi}

Çalışmada elde edilen verilerin analizinde içerik analizi kullanılmıştır. İçerik analizinde asıl amaç verileri anlamlandırabilecek kavramlara ve bağlantılara ulaşmaktır. İçerik analizinde elde edilen veriler ayrıntılı bir şekilde incelenmektedir (Krippendorff, 2004).

İlkokul birinci sınıf öğrencilerin çizdikleri resimler görüşmelerdeki açıklamaları da dikkate alınarak analiz edilmiştir. Her bir öğrencinin çizimleri ayrı ayrı analiz edilmiştir. İlkokul birinci sınıf öğrencilerin çizimleri, görüşmeler esnasında belirlenen temalar tespit edilerek ortak olan kavramlar kategorize edilmiştir.

Öğrenci görüşlerini kodlamak amacıyla erkek öğrenciler için Ali, Mete, Onur, Talat, Harun, Kerem, İsa, Umut, Ünal, Yusuf; kız öğrencileri için Ela, Lale, Nil, Esma, Bengü, Şule, Ceren, Jale kod isimler verilmiştir. Sıfır atık kavramı için tespit edilen temalar ve ortak kavramlar belirlenmiş ve öğrenci kodlarının yer aldığı tablo haline getirilmiştir. İlkokul birinci sınıf öğrencilerinin çizimlerinde tespit edilen öğeleri en iyi yansıtan çizimlere yer verilerek yorumlanmıştır.

\section{6. İnanırlık (Geçerlik) ve Tutarlılık}

Lincoln ve Guba'ya (1985) göre geçerlik için inandırıcılık ve aktarılabilirlik (transfer edilebilirlik) gereklidir. İnandırıcılığı (iç geçerlik) sağlamak amacıyla derinlik odaklı veri toplama, uzman incelemesi yöntemleri kullanılmıştır. Derinlik odaklı veri toplamaya çalışılmış ve toplanan veriler, verilerin analizi ve sonuçlar araştırma sürecinde uzman incelemesine sunulmuştur. Ortaya konulan çizimlerin kategori edilmesi sürecinde uzmanlardan gelen geribildirimler ve öneriler dikkate alınmıştır. Örneğin; ilk başta belirlenen atık bilinci, çevre koruma ve sorumluluk kategorileri uzmanlardan gelen geribildirimler sonucunda sıfır atık projesinin amaçları doğrultusunda atık bilinci, çevre koruma, sosyal sorumluluk ve paylaşma, israfı önleme şeklinde kategorize edilmiş ve öneriler doğrultusunda veriler, belirlenen temalar üzerinden analiz edilmiştir.

Araştırmanın iç geçerliliğini sağlamak için öğrencilerle görüşmeler yapılmış, öğrenciler sıfır atık kavramı ile ilgili çizimlerini anlatmaları istenmiştir. Böylece her birinden elde edilen bulgular, sıfir atık projesi kazanımları ve kavramları açısından karşılaştırmalı olarak incelenmiştir. Verilerin toplamasında kavramsal çerçeve rehber olarak alınmıştır (Demirel, Tuncel, Demirhan ve Demir, 2008).

Araştırmanın güvenirliği, Miles ve Huberman'ın (1994) formülü (Güvenirlik = Görüș Birliği $/$ Görüş Birliği + Görüş Ayrılığı x 100) kullanılarak hesaplanmıştır. İki farklı 
uzmanın yapmış olduğu kodlamalarda 37 kodda uzlaşı, 7 kodda ise uyuşmazlık tespit edilmiştir. Uzmanların yapmış olduğu kodlar arasındaki tutarlılık toplamda \%85 olarak belirlenmiştir. Güvenirlik hesaplarının \%70'in üzerinde olması durumunda araştırma güvenilir olarak kabul edilmektedir (Miles ve Huberman, 1994).

\section{Bulgular}

$\mathrm{Bu}$ bölümde araştırma süresince toplanan veriler alt problemlere uygun şekilde düzenlenip analiz edilmiş ve elde edilen bulgular tablolar aracılığıyla sunularak açıklanmıştır.

\subsection{Birinci alt probleme ilişkin bulgular}

İlkokul birinci sınıf öğrencilerinin "sıfır atık" ile ilgili zihinsel imgelerin kavramsal kategoriler altında kodlara göre dağılımı Tablo 1'de verilmiştir.

Tablo 1. İlkokul Birinci Sınıf Öğrencilerinin "Sıfır Atık" İle İlgili Zihinsel İmgelerin Kavramsal Kategoriler Altında Kodlara Göre Dağılımı

\begin{tabular}{ll}
\hline Kavramlar & Katılımcılar \\
\hline Çöp (Kağıt, Plastik, Cam v.b) & $\begin{array}{l}\text { Ela, Lale, Nil, Bengü, Şule, } \\
\text { Ceren, Jale, Ali, Mete, Onur, } \\
\text { Talat, Harun, Kerem, Umut }\end{array}$ \\
Geri Dönüşüm Kutuları & $\begin{array}{l}\text { Ela, Nil, Bengü, Şule, Ceren, } \\
\text { Jale, İsa }\end{array}$ \\
Geri Dönüşüm İşareti & $\begin{array}{l}\text { Ela, Nil, Bengü, Şule, Ceren, } \\
\text { Jale }\end{array}$ \\
Çöp Kutusu & Mete, Talat, Kerem, Umut \\
Çevresini Temizleyen Çocuk & Lale, Ali, Harun \\
Pil (Atık Pil) & Ünal, Yusuf \\
Bayat Ekmek & Esma \\
Çöpçü & Kerem \\
Çöp Arabası & Kerem \\
Giysi Toplama Kutusu & Nil \\
Oyuncak Toplama Kutusu & İsa \\
Bayat Ekmek Verilen Kedi & Esma \\
Pil Toplama Kutusu & Ünal \\
Yere Çöp Atan Çocuk & Mete \\
\hline Toplam & \\
\hline
\end{tabular}

Toplam

44

İlkokul birinci sınıf öğrencilerine sıfır atık kavramı ile ilgili resim çizmeleri ve çizdikleri resimleri açıklamaları istenmiştir. İlkokul birinci sınıf öğrencilerinin çizimlerinde geçen kavramlar ile ilgili Tablo 1 incelendiğinde en fazla çöp kavramının çizildiği tespit edilmiştir. Çöp kavramı ile ilgili olarak aşağıda bazı öğrenci görüşlerine yer verilmiştir;

\section{Ali: "Çocuklar etrafa çöpleri atmışlar."}

Lale: “Çöpleri geri dönüşüm kutularına atmışlar."
Ceren: "Yerlere çöpler atılmış, her yer çok pis."

Harun: "Çocuklar yiyeceklerin kabuklarını yere atmışlar." Jale: "Çöpleri geri dönüşüm kutusunun içine atmışlar."

Talat: "Plastik su şişelerini çöp kutusuna atmışlar."

Umut: "Yerdeki çöpler toplayıp çöp kutusuna atıyorlar."

Öğrenci görüşleri dikkate alındığında ilkokul birinci sınıf öğrencilerinin çevrelerindeki çöp ile ilgili unsurlara, insanların çevreye yönelik davranışlarına dikkat ettikleri söylenebilir. İnsanların çevreye yönelik hem olumlu hem de olumsuz davranışlara örnek verdikleri belirlenmiştir. Öğrencilerin günlük yaşantı alanlarında çevre ile ilgili olayları önemsedikleri söylenebilir. Ancak ilkokul birinci sınıf öğrencileri çevreye yönelik olumsuz davranışlarda bulunan kişilere karşı bir uyarıda bulunma davranışı göstermemişlerdir.

\section{2. İkinci alt probleme ilişkin bulgular}

İlkokul birinci sınıf öğrencilerinin "sıfır atık" ile ilgili çizimlerindeki temaların cinsiyet değişkenine göre dağılımı Tablo 2'de verilmiştir.

Tablo 2. İlkokul Birinci Sınıf Öğrencilerinin "Sıfır Atık” ile İlgili Çizimlerindeki Kavramların Temalarının Cinsiyete Göre Dağılımı

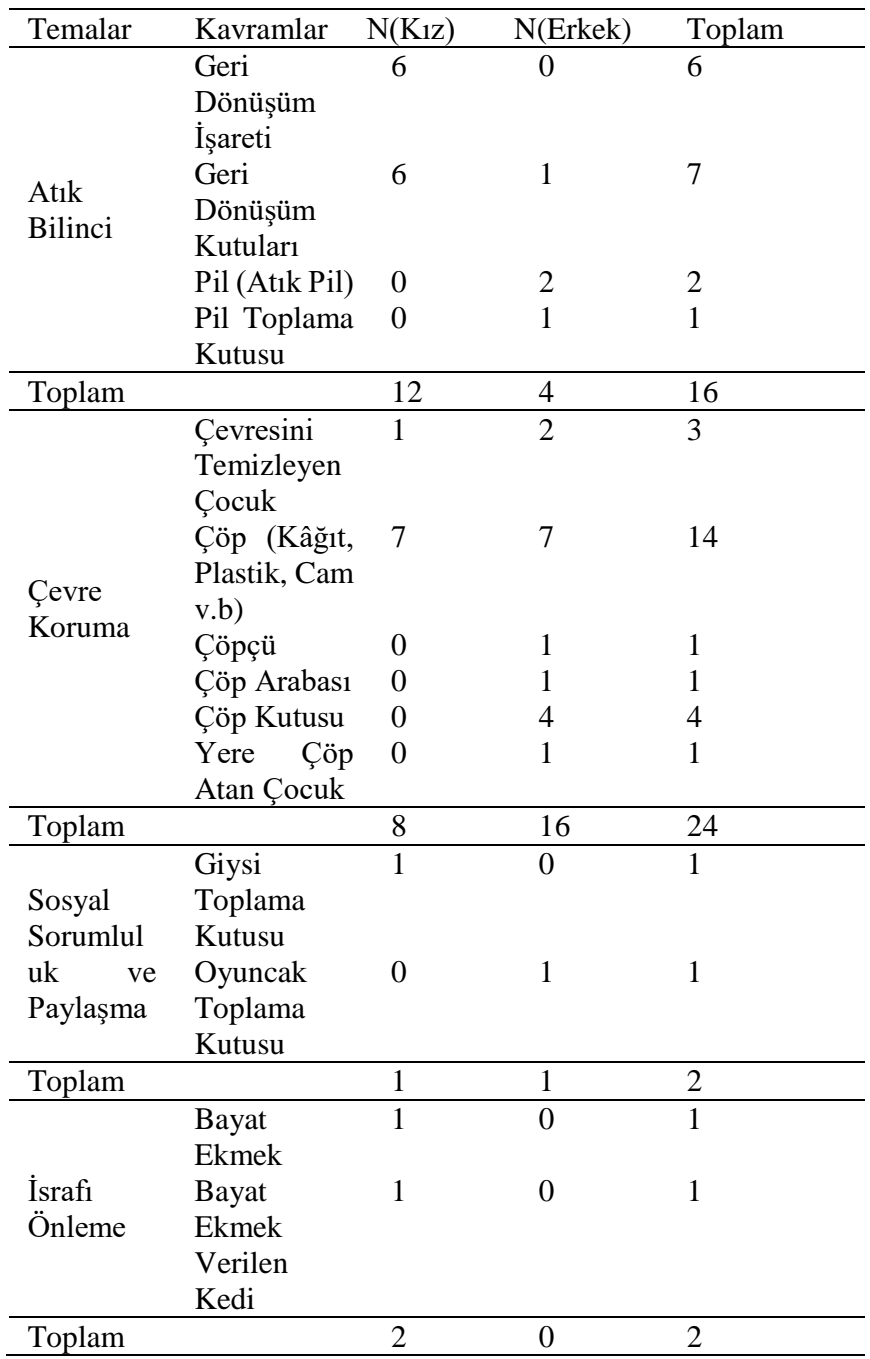

Tablo 2 incelendiğinde ilkokul birinci sınıf öğrencilerinin sıfır atık kavramı ile ilgili çizimlerinden atık bilinci, çevre 
koruma, sosyal sorumluluk ve paylaşma, israfi önleme olmak üzere 4 tema oluşturulmuştur.

Oluşturulan temalar incelendiğinde öğrencilerin atıkların ayrıştırılması, çevre temizliği, kaynakların doğru kullanımı, sokak hayvanlarının korunması, yardımlaşma ve paylaşma konularına dikkat çektikleri söylenebilir.

Atık bilinci temasında en fazla geri dönüşüm işareti ile geri dönüşüm kutuları kavramına, çevre koruma temasında ise çöp (Kâğıt, Plastik, Cam vb.) kavramına yer verildiği belirlenmiştir. İlkokul birinci sınıf öğrencilerinden kız ögrencilerin atık bilinci teması, erkek öğrencilerin çevre koruma teması ile ilgili daha fazla kavram çizdikleri tespit edilmiştir. Buradan hareketle k1z öğrencilerin erkek öğrencilere göre çöplerin ve atıkların ayrıştırılması konusunda daha hassas oldukları söylenebilir.

İlkokul birinci sınıf öğrencilerinin sıfır atık kavramı ile ilgili çizdikleri resimlere örnekler aşağıda yer verilmektedir.

Çizim 1. İlkokul Birinci Sınıf Öğrencisinin Sıfır Atık KavramıAtık Bilinci Teması ile İlgili Çizdiği Resim (Ela)

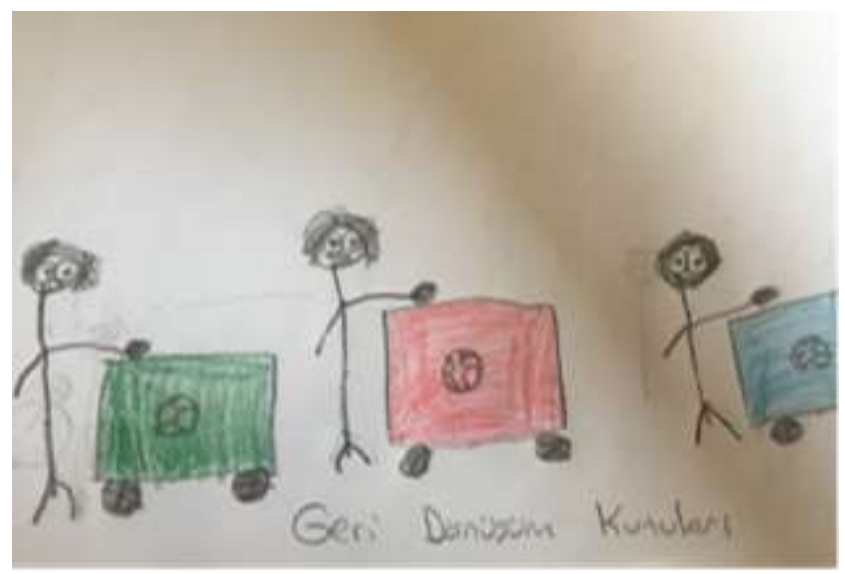

Çizim 1'de ilkokul birinci sınıf öğrencisinin, yaptığ1 resimde sıfır atık kavramını atık bilinci ile ilişkilendirdiği görülmektedir. Öğrenciden çizimini anlatması istendiğinde öğrenci (Ela); “Çocuklar kâğıt, cam ve plastik atıkları ayrı ayrı çöp kutularına atıyor." şeklinde ifade etmiştir. Bu öğrenci için atıkların ayrı toplanması bilincinin geliştiği söylenebilir.

Çizim 2. İlkokul Birinci Sınıf Öğrencisinin Sıfır Atık KavramıÇevre Koruma Teması ile İlgili Çizdiği Resim (Kerem)

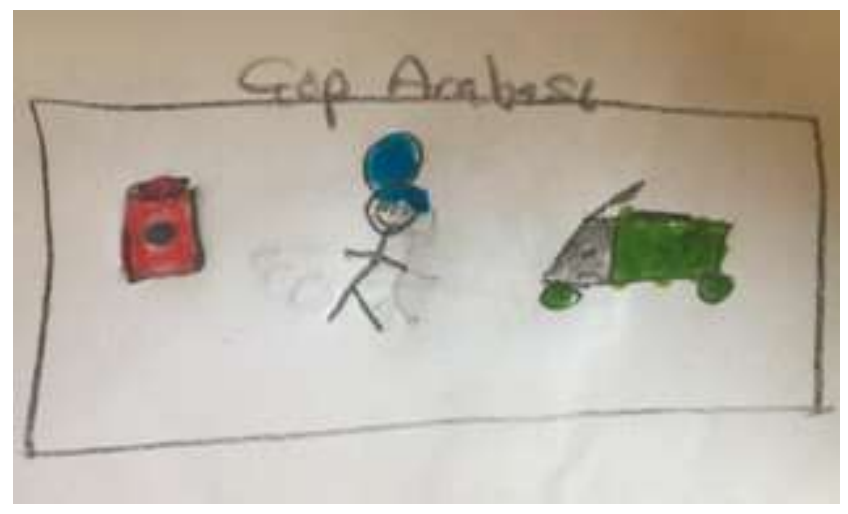

Çizim 2'de ilkokul birinci sınıf öğrencisinin, yaptığ resimde sıfır atık kavramını çevre koruma ile ilişkilendirdiği görülmektedir. Öğrenciden çizimini anlatması istendiğinde öğrenci (Kerem); "Çöpçü, çöp arabası ile geliyor. Çöp kutusunu boşaltıyor.” şeklinde ifade etmiştir. Bu öğrenci çevresindeki çevre koruma ile ilgili olaya ve meslek çalışanına dikkat çekmiştir. Bu nedenle çevremizdeki çevre koruma ile ilgili çalışmaların öğrenciler açısından ilgi çekici olduğu söylenebilir.

Çizim 3. İlkokul Birinci Sınıf Öğrencisinin Sıfır Atık KavramıSosyal Sorumluluk ve Paylaşma Teması ile İlgili Çizdiği Resim (Nil)

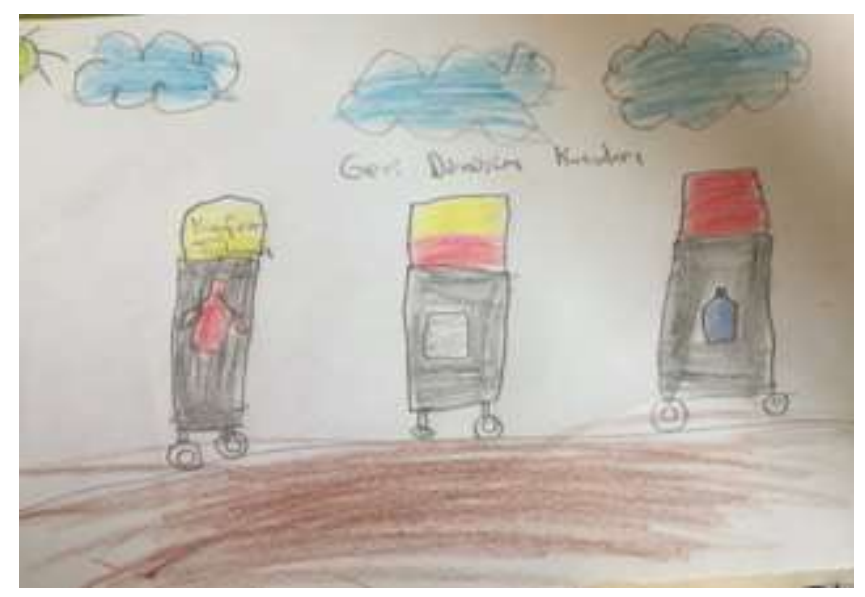

Çizim 3'de ilkokul birinci sınıf öğrencisinin, yaptığ resimde sıfır atık kavramını sosyal sorunluluk ve paylaşma ile ilişkilendirdiği görülmektedir. Öğrenciden çizimini anlatması istendiğinde öğrenci (Nil); "Kâğıt ve plastik geri dönüşüm kutularının yanında eski kıyafetlerin atıldığ kıyafet toplama kutusu var. Kullanılmayan, küçülen giysiler buraya atılıyor." şeklinde ifade etmiştir. Bu öğrenci atıkların ayrı toplanmasının yanında günlük yaşamında çevresinde gördüğü kıyafet toplama kumbarasına yer vermiştir. Öğrencilerin çevrelerinde yer alan kullanılmayan eşyaların ihtiyaç sahibi kişilerle paylaşılması konusunda hassas oldukları söylenebilir. $\mathrm{Bu}$ yönüyle öğrencilerin, yardımlaşma ve sosyal sorumluluk bilinçlerinin de yüksek olduğu söylenebilir.

Çizim 4. İlkokul Birinci Sınıf Öğrencisinin Sıfır Atık KavramıSosyal Sorumluluk ve Paylaşma Teması ile İlgili Çizdiği Resim (İsa)

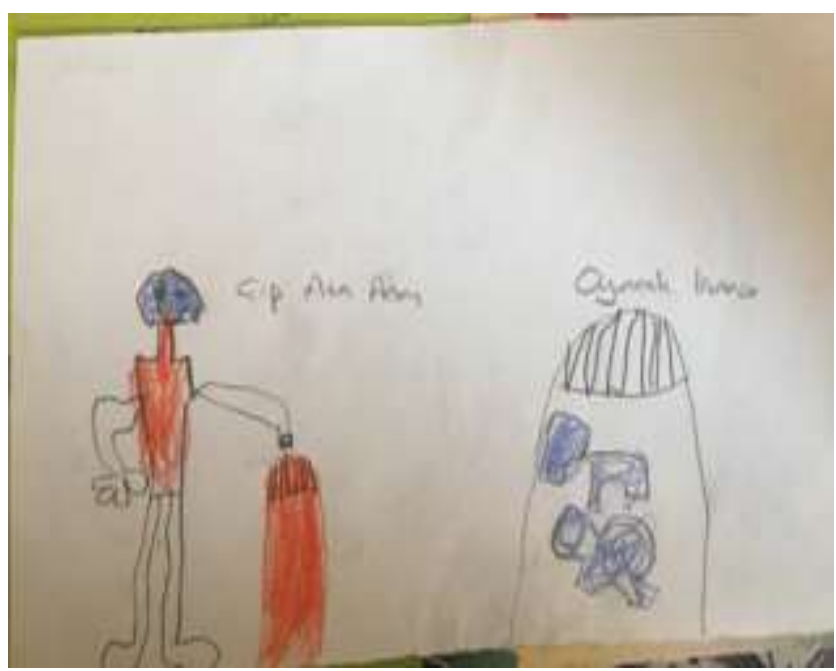


Çizim 4'de ilkokul birinci sınıf öğrencisinin, yaptığı resimde sıfır atık kavramını sosyal sorumluluk ve paylaşma ile ilişkilendirdiği görülmektedir. Öğrenciden çizimini anlatması istendiğinde öğrenci (İsa); "Çocuk eskiyen, kırılan ve oynamadığı oyuncaklarını oyuncak kutusuna atıyor. Buradan diğer çocuklar istediği oyuncağı alıyor." şeklinde ifade etmiştir. Bu öğrenci çevresinde yer alan oyuncak toplama kutusuna dikkat çekmiştir. Öğrencilerin çevrelerinde yer alan sosyal sorumluluk kapsamında paylaşma temelli etkinliklerin sıfır atık projesi ile ilişkilendirmeleri dikkat çekicidir.

Çizim 5. İlkokul Birinci Sınıf Öğrencisinin Sıfır Atık Kavramıİsrafı Önleme Teması ile İlgili Çizdiği Resim (Esma)

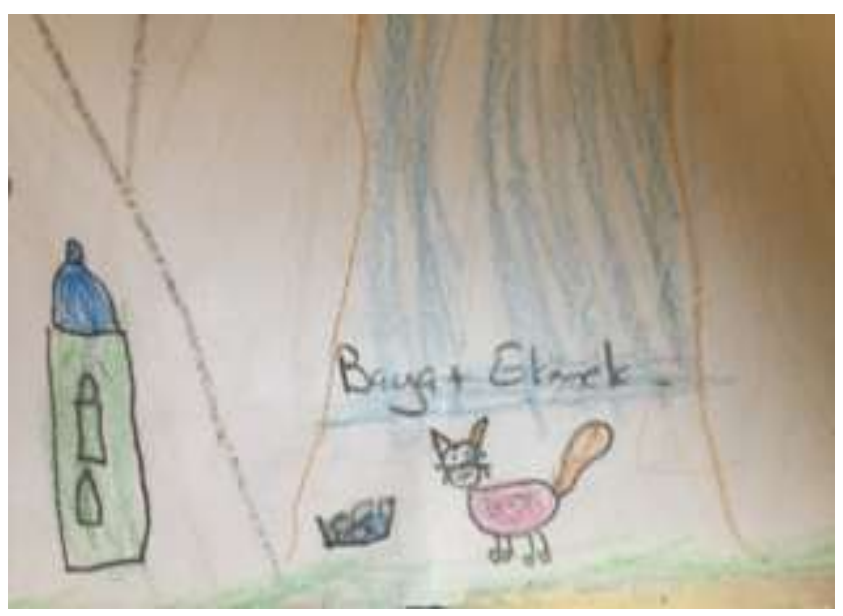

Çizim 5' de ilkokul birinci sınıf öğrencisinin, yaptığı resimde sıfır atık kavramını israfı önleme ile ilişkilendirdiği görülmektedir. Öğrenciden çizimini anlatması istendiğinde öğrenci (Esma); "Evimizde kuruyan ekmekleri 1slatıp hayvanlara vermeliyiz." şeklinde ifade etmiştir. Bu öğrenci evinde kullanılmayan ekmeklerin israf edilmemesi ve çevremizdeki sokak hayvanlarının yaşamlarını sürdürebilmeleri için onlara verilmesi gerektiğini düşünmektedir. Öğrencilerin hem kaynakların israf edilmemesine hem de çevrelerindeki sokak hayvanlarına karşı hassas oldukları söylenebilir. Bu çizimin sadece kız öğrenci tarafından yapılması k1z öğrencilerin erkek öğrencilere göre kaynakların israf edilmemesi ve sokak hayvanlarının korunması konusunda daha fazla hassas olduklarını gösterebilir.

Çizim 6. İlkokul Birinci Sınıf Öğrencisinin Sıfır Atık KavramıÇevre Koruma Teması ile İlgili Çizdiği Resim (Şule) (Olumlu Örnek)

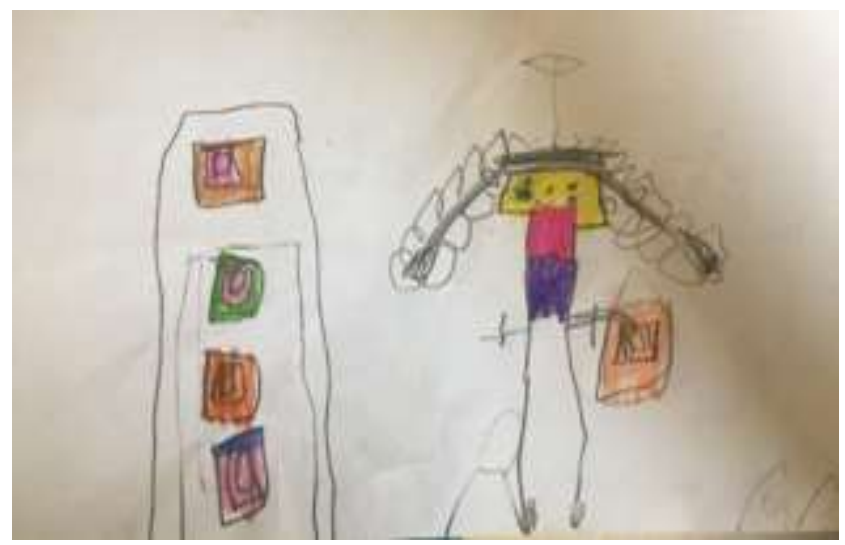

Çizim 6'da ilkokul birinci sınıf öğrencisinin, yaptığ resimde sıfır atık kavramını çevre koruma ile olumlu örnekle ilişkilendirdiği görülmektedir. Öğrenciden çizimini anlatması istendiğinde öğrenci (Şule); "Çevresini temizleyen çocuk, çöpleri geri dönüşüm kutusuna atıyor." şeklinde ifade etmiştir. Bu öğrenci çevresindeki insanların çevreye yönelik korumacı davranışlarına dikkat çekmiştir.

Çizim 7. İlkokul Birinci Sınıf Öğrencisinin Sıfır Atık KavramıÇevre Koruma Teması ile İlgili Çizdiği Resim (Mete) (Olumsuz Örnek)

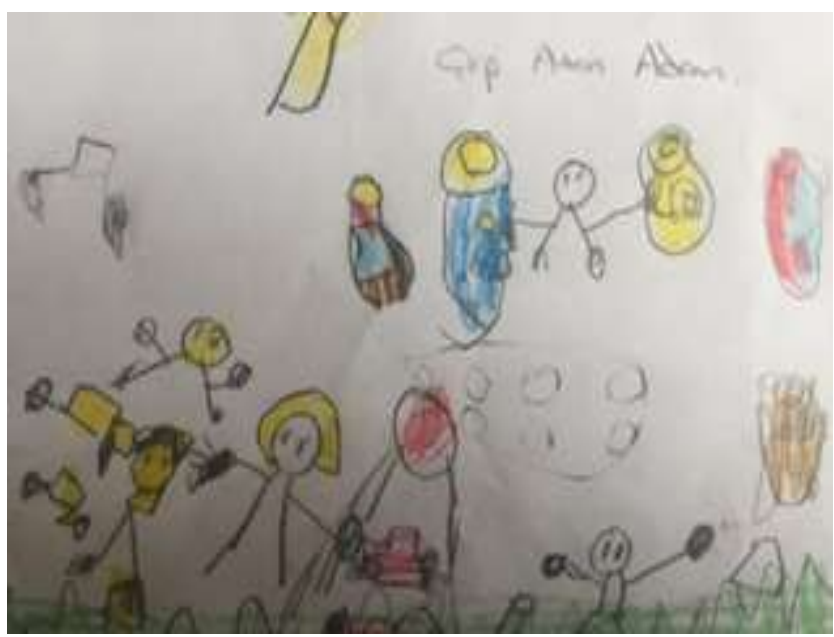

Çizim 7'de ilkokul birinci sınıf öğrencisinin, yaptığı resimde sıfır atık kavramını çevre koruma ile olumsuz örnekle ilişkilendirdiği görülmektedir. Öğrenciden çizimini anlatması istendiğinde öğrenci (Mete); "Çocuklar etrafa çöp atıyor, her yeri kirletiyorlar." şeklinde ifade etmiştir. Bu öğrenci çevresinde yer alan insanların çevreye yönelik olumsuz davranışlarına dikkat çekmiştir.

\section{Tartışma, Sonuç ve Öneriler}

$\mathrm{Bu}$ bölümde araştırma sonucunda elde edilen sonuçlar araştırma soruları doğrultusunda tartışılmıştır.

Araştırmanın birinci alt probleminde ifade edilen ilkokul birinci sınıf öğrencilerinin sıfır atık ile ilgili çizimlerindeki kavramların neler olduğundan hareketle 14 farklı kavram çizdikleri, en fazla çöp (Kâğıt, Plastik, Cam vb.) kavramı ile ilgili çizimler yaptıkları sonucu elde edilmiştir. Bu sonuçlar literatürde Pınar ve Yakışan (2017), Yalçınkaya (2013), Sadık, Çakan ve Artut'un (2011) çalışmaları ile benzerlik taşımaktadır.

Pınar ve Yakışan (2017) çalışmalarında ilkokul öğrencilerinin çevre ile ilgili çizimlerinde çevre kirliliği olarak çöp kavramına tüm sınıf düzeylerinde en fazla yer verildiği belirlenmiştir. Yalçınkaya (2013) tarafından yapılan çalışmada sekizinci sınıf öğrencilerinin çevre sorunları ile ilgili çizdikleri karikatürlerde çöp sorununu ele alan çizimler yaptıkları tespit edilmiştir. Sadık, Çakan ve Artut (2011) tarafindan yapılan çalışmada ise beşinci sınıf öğrencilerinin çevre sorunlarına yönelik çizimlerinde en fazla çöp figürlerine yer verdikleri belirlenmiştir. Bu durum çöpün, çocuklar tarafından çevre sorunu olarak algılandığ şeklinde yorumlamıştır. Bu sonuç bu araştırmanın temel bulgularından olan ilkokul birinci sınıf öğrencilerinin atık kavramı ile ilgili etmenin çöp kavramı algısıyla uyum göstermektedir. Bu durumun çocukların çevre sorunlarının asıl nedeninin çevreye çöp atılmasından kaynaklandığını düşünmeleridir. 
İlkokul birinci sınıf öğrencilerinin sıfır atık kavramı ile ilgili yaptıkları çizimler, öğrencilerin açıklamaları doğrultusunda atık bilinci, çevre koruma, sosyal sorumluluk ve paylaşma, israfı önleme olmak üzere 4 tema üzerinde değerlendirilmiştir.

Araştırmanın ikinci alt probleminde ifade edilen ilkokul birinci sınıf öğrencilerinin sıfır atık kavramı ile ilgili çizimlerindeki kavramların/temalarının cinsiyete göre dağılımından hareketle en fazla çevre koruma teması ile ilgili kavramlar çizildiği, bu çizimlerin daha fazla ilkokul birinci sınıfta öğrenim gören erkek öğrenciler tarafından yapıldığı tespit edilmiştir. Bu durum araştırmaya katılan ilkokul birinci sınıfta öğrenim gören erkek öğrenci sayısının fazla olmasından kaynaklanmış olabileceğidir. İlkokul birinci sınıfta öğrenim gören kız öğrencilerin ise en fazla atık bilinci teması ile ilgili kavramlar çizdikleri belirlenmiştir. $\mathrm{Bu}$ sonuçlar literatürde Mrema (2008) tarafından yapılan çalışma ile benzerlik taşımaktadır. Bu araştırmacı çalışmasında kız öğrencilerin erkek öğrencilere kıyasla geri dönüşüm ve atık bilinci konusunda daha bilgili olduklarını tespit etmiştir. Ancak öğrencilerin bilgilerini davranışa dönüştürmelerinde yeterli olmadıklarını da belirlemiştir.

Çevresel risk algıları hem bireyden bireye hem de cinsiyet, 1rk, toplumsal sınıf gibi unsurlara göre değişmektedir (Garrard, 2016). Bu araştırmada ilkokul birinci sınıf öğrencilerinin sıfır atık algıları kız öğrencilerin atık bilinci ve geri dönüşüm, erkek öğrencilerin çevre koruma ve çevre temizliği ile ilgili olduğu sonucuna varılmıştır.

$\mathrm{Bu}$ araştırmanın sonucu doğrultusunda olduğu gibi Pınar ve Yakışan (2017), Yalçınkaya (2013), Sadık, Çakan ve Artut'un (2011) yaptıkları çalışmalarda farklı sınıf düzeyindeki öğrencilerin çevre sorunları ile ilgili çizimlerde en fazla çöp figürlerine yer verdikleri tespit edilmiştir. Böylece tüm öğretim kademesinde öğrenim gören öğrencilerin atık ve çevre sorunları algısının temel etmeni olarak çevrede yer alan çöplerin oluşturduğu söylenebilir.

Araştırmanın birinci alt probleminden elde edilen sonuçlardan hareketle yapılan bazı çizimlerde çevreyi kirleten ve atıkların oluşmasına neden olan insan faktörüne yer verilmesi bu sorunun çözümünde insanların çevre konusunda eğitilmesi ve hassasiyetlerinin artırılması gerektiği önem kazanmaktadır. Bu doğrultuda öğrencilere ilkokuldan başlanarak çevre eğitimi verilerek, insanın doğa ile olan ilişki düzeni, doğal ekolojik sistem, doğal beslenme zinciri ve doğal kaynakların tüketimi ile ilgili bilgilendirilmeleri gerekmekte olup bu eğitimin yükseköğretim de dahil olmak üzere tüm eğitim kademlerinde yer verilmesi önerilebilir. Bu sayede insanlar, çevreye yönelik bütünsel bir bakış kazanarak, bireyin, çevre ile bütünlüğü ve bu bütün içerisindeki konumunu algılaması sağlanabilecektir (Sungur, 2017).

İlkokul birinci sınıf öğrencilerine sıfır atık ve çevre konusunda verilen eğitimlerin teoride kalmayıp davranışa dönüşebilmesi amacıyla etkinlikler tasarlanması için gerekli önlemlerin alınması önerilebilir. Bunun için ilgili ders öğretim programlarında yer alan kazanımlar ve yaşanılan çevre doğrultusunda çevre eğitimi ve sıfır atık projesi ile ilgili ders içi ve ders dışı etkinliklere yer verilmelidir.
Araştırmanın ikinci alt probleminden elde edilen sonuçlardan hareketle ilkokul birinci sınıf öğrencilerinin atık ve çevre bilincini geliştirecek projelerde aktif görevler almaları önerilebilir. İlkokul birinci sınıfta okuyan özellikle erkek öğrencilerin atık ve çevre koruma ile ilgili gözlem yapmaları ve çizgi filmler, animasyonlar, belgeseller izlemeleri ve eğitim ortamlarının bu yönde zenginleştirilmesi, eğitim ortamlarının hazırlayıcısı olan öğretmenlere sıfır atık eğitimi konusunda hizmet içi eğitimlerin düzenlenmesi, öğretmenlerin bu eğitimlere katılmaları önerilebilir. Öğrencilerin bilgilerini davranışa dönüştürebilmesi için toplum-okul-aile iş birliği içerisinde gerekli durum ve ortamların oluşturulmasının önemli olacağı düşünülebilir.

İlkokul birinci sınıf öğrencilerinin sıfır atık ve çevre koruma ile ilgili algılarının daha önceki eğitim döneminin (okul öncesi-anaokulu), aile içi eğitimin ve medyanın etkisinin olduğu düşünülmektedir. Düşünülen bu etki unsurlarının etkisini ortaya koyabilecek yeni çalışmaların yapılması önerilebilir.

2023 eğitim vizyonu kapsamında sıfır atık projesinin okullarımıza entegrasyonunun sağlanması amacıyla gerekli eğitimlerin eğitim yöneticilerine ve öğretmenlerimize verilmesi önem kazanmıştır.

\section{Kaynakça}

Arıkurt, E. (2014). Kavram karikatürlerinin ve kavramsal değişim metinlerinin ortaokul 7. sinıf ögrencilerinin başarılarına, kavramsal değişimlerine ve tutumlarına etkisinin karşılaştırılması (Yüksek lisans tezi). Yükseköğretim Kurulu Ulusal Tez Merkezi'nden edinilmiştir. (Tez No.380637)

Atılğanlar, N. (2014). Kavram karikatürlerinin ilköğretim yedinci sinıf ögrencilerinin basit elektrik devreleri konusundaki kavram yanılgllarl üzerindeki etkisi (Yüksek lisans tezi). Yükseköğretim Kurulu Ulusal Tez Merkezi'nden edinilmiştir. (Tez No.378513)

Aydın, G. (2013). Fen bilgisi ve sınıf ögretmen adaylarının ağır metal ve radyasyon kirliliği konusunda bilgi düzeyleri: Giresun Üniversitesi Örneği (Yüksek lisans tezi). Yükseköğretim Kurulu Ulusal Tez Merkezi'nden edinilmiştir. (Tez No.380636)

Bulut, E. ve Çavuldur, L. (2017). Geri dönüşümlü kâğıt hamurunun yaratım malzemesi olarak görsel sanatlar eğitiminde kullanımının öğrencilerde kâğıdın geri dönüşümü hakkında bilgi ve alışkanlık kazanımına yönelik etkileri. Uluslararası Afro-Avrasya Araştırmaları Dergisi, 2(4), 187-208.

Creswell, J. W. (2017). Nitel araştırmacılar için 30 temel beceri. (H. Özcan, Çev.) Ankara: Anı Yayıncılık.

Creswell, J. W. (2009). Research design, qualitative, quantitative, and mixed methods approaches. California: SAGE Publications.

Çabuk, B. (2019). Çevre eğitimi. D. Kahriman-Pamuk (Ed.), Erken çocukluk döneminde çevre eğitimi ve sürdürülebilirlik içinde, (ss. 1-38). Ankara: Anı Yayıncilik. 
Çakır-Koçak, Y., Tuna-Oran, N. ve Çeber-Turfan, E. (2016). İlköğretim öğrencilerine verilen atıkların ayrıştırılması eğitiminin bilgi transferi ile aile bilgi düzeyine etkisi. Hemşirelik Akademik Araştırma Dergisi, 2(1), 1-8.

Çimen, O. ve Yılmaz, M. (2012). İlköğretim öğrencilerinin geri dönüşümle ilgili bilgileri ve geri dönüşüm davranışları. Uludă̆ Üniversitesi Ĕ̆itim Fakültesi Dergisi, 25(1), 63-74.

Demir, Y. (2008). Kavram yanılgılarının belirlenmesinde kavram karikatürlerinin kullanılması (Yüksek lisans tezi). Yükseköğretim Kurulu Ulusal Tez Merkezi'nden edinilmiştir. (Tez No.232374)

Demiral, B. ve Evin, H. (2018). Malatya'da katı atık yönetimi: kentleşmenin yerel çevre politikaları üzerine etkisi. Social Sciences Research Journal, 7, 277-295.

Demirel, Ö., Tuncel, İ., Demirhan, C. ve Demir, K. (2008). Çoklu zekâ kuramı ile disiplinlerarası yaklaşımı temel alan uygulamalara ilişkin öğretmen-öğrenci görüşleri. Eğitim ve Bilim, 33(147), 14-25.

Erdoğan, A. ve Özsevgeç, L. C. (2012). Kavram karikatürlerinin öğrencilerin kavram yanılgılarının giderilmesi üzerindeki etkisi: sera etkisi ve küresel 1sınma örneği. Turkish Journal of Education, 1(2), 113.

Ersoy, A. F. ve Türkkan, B. (2010). İlköğretim öğrencilerinin çizdikleri karikatürlere yansıttıkları sosyal ve çevresel sorunların incelenmesi. Eğitim ve Bilim, 35(156), 96-109.

Ersoy, A. ve Türkkan, B. (2009). İlköğretim öğrencilerinin resimlerinde internet algısı. Ilkögretim Online, 8(1), 57-73.

Garrard, G. (2016). Ekoeleştiri-ekoloji ve çevre üzerine kültürel tartışmalar. (E. Genç, Çev. Ed.) İstanbul: Kolektif Kitap.

Gönüllü, M. ve Çelik, Z. (2015). İlköğretim öğrencilerinin çevre için zararlı ambalaj atıkları hakkında farkındalığı (İstanbul örneği). Milli Eğitim Dergisi, 45(205), 44-63.

Gültekin, S. T. (2013). Kavram karikatürleri ile zenginleştirilmiş matematik ögrenme ortamlarından yansımalar (Yüksek lisans tezi). Yükseköğretim Kurulu Ulusal Tez Merkezi'nden edinilmiştir. (Tez No.344468)

Gürer, A. ve Sakız, G. (2018). Yetişkinlerin küresel ısınma ile ilgili bilgi düzeyleri ve geri dönüşüm farkındalıkları. Insan ve Toplum Bilimleri Araştırmaları Dergisi, 7(2), 1364-1391.

Howitt, D., \& Cramer, D. (2014). Research methods in psychology. Harlow, England: Pearson.

Kaçtıoğlu, S. ve Şengül, Ü. (2010). Erzurum kenti ambalaj atıklarının geri dönüşümü için tersine lojistik ağ1 tasarımı ve bir karma tam sayılı programlama modeli. Atatürk Üniversitesi İktisadi ve İdari Bilimler Dergisi, 24(1), 89-112.
Krippendorff, K. (2004). Content analysis: An introduction to its methodology. Thousand Oaks, CA: Sage Publications.

Lincoln, Y. S., \& Guba, E. G. (1985). Naturalistic inquiry. beverly hills, CA: Sage Publications.

MEB (2018). Ilköğretim 1, 2 ve 3. Sinıflar Hayat Bilgisi Dersi Ögretim Programı. Ankara: Millî Eğitim Bakanlığı Talim ve Terbiye Kurulu Başkanlığı.

Meriç, G. (2014). Fen ve teknoloji dersinde kavram karikatürlerinin ögrencilerin kavramsal anlama, motivasyon ve tutum düzeyleri üzerine etkisi (Yüksek lisans tezi). Yükseköğretim Kurulu Ulusal Tez Merkezi'nden edinilmiştir. (Tez No.373795)

Miles, M. B. \& Huberman, A. M. (1994). Qualitative data analysis (2nd ed.). Thousand Oaks, CA: Sage.

Mrema, K. (2008). An assessment of students'environmental attitudes and behaviours and the effectiveness of their school recycling programs (Yüksek lisans tezi). ProQuest Dissertations \& Theses Global adresinden edinilmiștir. (UMI No. 10222/76596)

Mutlu, M. (2013). "Recycling" concepts perceptions of grade eihgth students: phenomenographic analysis. Anthropologist 16(3), 663-669.

Önal, H., Kaya, N. ve Çalışkan, T. (2019). Çevre eğitiminde sıfır atık politikası ve mevcut ders kitaplarındaki görünümü (Hayat bilgisi 2. sınıf ders kitabı). Milli Eğitim Dergisi, 48(221), 123-140

Özsoy, S. ve Ahi, B. (2014). İlkokul öğrencilerinin geleceğe yönelik çevre algılarının çizdikleri resimler aracılığ 1 ile belirlenmesi. Kuram ve Uygulamada Eğitim Bilimleri, 14 (4), 1557-1582.

Pınar, E. ve Yakışan, M. (2017). İlkokul öğrencilerinin çevre kavramları ile ilgili çizimlerinin analizi. Trakya Üniversitesi Ĕ̆itim Fakültesi Dergisi (USOS 2016 Özel Saylsi), 8(1), 97-113.

Rodari, P. (2007). Science and scientists in the drawings of European children. Journal of Science Communication, 6(3), 1-12.

Sadık, F., Çakan, H. ve Artut, K. (2011). Çocuk resimlerine yansıyan çevre sorunlarının sosyo-ekonomik farklılıklara göre analizi. Ilköğretim Online, 10(3),1066-1080.

Say, F. S. (2011). Kavram karikatürlerinin 7. sınıf ögrencilerinin "maddenin yapisı ve özellikleri" konusunu ögrenmelerine etkisi (Yüksek lisans tezi). Yükseköğretim Kurulu Ulusal Tez Merkezi'nden edinilmiştir. (Tez No.298690)

Sıfır Atık Yönetmeliği (2019, 12 Temmuz). Resmî Gazete (Sayı: 30829). Erişim adresi: https://www.resmigazete.gov.tr/eskiler/2019/07/2019 0712-9.htm

Sungur, S. A. (2017). Lisans öğrencilerinin çevreye yönelik etik tutumları. Akademik Sosyal Araştırmalar Dergisi, 5 (41), 469-479. 
Tokiz, A. (2013). Illköğretim 6. 7. ve 8. sinıf öğrencilerinin kuvvet ve hareket konusundaki kavramsal anlama düzeylerinin kavram karikatürleri, kavram haritasl, çizimler ve görüşmeler kullanılarak değerlendirilmesi (Yüksek lisans tezi). Yükseköğretim Kurulu Ulusal Tez Merkezi'nden edinilmiştir. (Tez No.337090)

Türkiye Cumhuriyeti Çevre ve Şehircilik Bakanlığı. (2018). Sifir Atık Projesi. http://www.sifiratik.gov.tr adresinden 17/09/2019 tarihinde alınmıştır.

Ural-Keleş, P. ve Keleş, M. (2018). İlkokul 3. ve 4. sınıf öğrencilerinin geri dönüşüm kavramı ile ilgili algıları. Erzincan Üniversitesi Eğitim Fakültesi Dergisi, 20(2), 481-498.
Yalçınkaya, E. (2013). İlköğretim 8. sınıf öğrencilerine göre çevre sorunları: Nitel bir çalışma. Marmara Coğrafya Dergisi, 27, 416-439.

Yavuz, S. ve Büyükekşi, C. (2011). Kavram karikatürlerinin 1S1-S1caklık kavramlarının öğretiminde kullanılması. Karaelmas Fen ve Mühendislik Dergisi, 1(2), 25-30.

Yıld1z, İ. (2008). Kavram karikatürlerinin kavram yanılgilarının tespitinde ve giderilmesinde kullanılması: düzgün dairesel hareket (Yüksek lisans tezi). Yükseköğretim Kurulu Ulusal Tez Merkezi’nden edinilmiştir. (Tez No.218462) 